\title{
Göbekli Tepe: A Brief Description of the Environmental Development in the Surroundings of the UNESCO World Heritage Site
}

\author{
Daniel Knitter $^{1, *(\mathbb{D})}$, Ricarda Braun ${ }^{2,3}$, Lee Clare ${ }^{3 \oplus}$, Moritz Nykamp ${ }^{2, *(\mathbb{D}}$ and Brigitta Schütt ${ }^{2}$ \\ 1 Physical Geography, Department of Geography, Christian-Albrechts-Universität zu Kiel, \\ Ludewig-Meyn-Strasse 14, 24118 Kiel, Germany \\ 2 Physical Geography, Institute of Geographical Sciences, Freie Universität Berlin, Malteserstrasse 74-100, \\ 12449 Berlin, Germany; ricarda.braun@fu-berlin.de (R.B.); Brigitta.Schuett@fu-berlin.de (B.S.) \\ 3 Orient Department, German Archaeological Institute, Podbielskiallee 69-71, 14195 Berlin, Germany; \\ lee.clare@dainst.de \\ * Correspondence: knitter@geographie.uni-kiel.de (D.K.); m.nykamp@fu-berlin.de (M.N.); \\ Tel.: +49-431-880-2941 (D.K.); +49-30-838-70604 (M.N.)
}

Received: 5 March 2019; Accepted: 18 April 2019; Published: 24 April 2019

\begin{abstract}
This contribution provides a first characterization of the environmental development for the surroundings of the UNESCO World Heritage site of Göbekli Tepe. We base our analyses on a literature review that covers the environmental components of prevailing bedrock and soils, modeland proxy-based climatic development, and vegetation. The spatio-temporal scales that are covered are mainly the Eastern Mediterranean region and the Late Quaternary-whereby special attention is given to available data from the close vicinity of Göbekli Tepe. Information on Late Quaternary geomorphodynamics is largely absent for the environs of Göbekli Tepe, we therefore included remote sensing data, different terrain modeling approaches and field-based geomorphological mapping to gain insights into past process dynamics. The findings indicate that the environmental conditions at Göbekli Tepe during its time of occupation differed significantly from today, showing denser vegetation and a wide spread sediment cover. Different hypotheses are developed that aim to guide future research on environmental changes and their variations during the Late Pleistocene and Holocene. These activities are crucial for a more profound understanding of the environment of the site, its potential perception by humans and therefore for the development of narratives on their landscape creation motives.
\end{abstract}

Keywords: Pre-Pottery Neolithic; geomorphology; geomorphometry; paleoenvironment; paleoclimate

\section{Introduction}

Göbekli Tepe stands out as one of the most important prehistoric discoveries of recent decades, most notably due to its monumental architecture with its monolithic T-shaped pillars, some of which feature outstanding symbolic imagery, including engravings as well as high and low reliefs. This imagery provides unprecedented insights into hunter-gatherer belief systems at the transition to food-producing economies in the Early Holocene (cf. [1-3]). Göbekli Tepe (Potbelly Hill) was initially recognized in the early 1960s by a joint Turkish-American archaeological survey team in the frame of the Prehistoric Research in Southeastern Anatolia project [4]. In 1995, fieldwork began under the auspices of the Şanlıurfa Museum in close collaboration with the German Archaeological Institute (DAI). 
The prehistoric site Göbekli Tepe features an artificial mound (höyük) comprised of archaeological deposits that accumulated upon a limestone plateau of the Germuş mountain range (c. $770 \mathrm{~m}$ above sea level) from the mid-10th to the late-9th millennium BCE (c. 11.5-10 ka BP) [1]. This period corresponds to the early Pre-Pottery Neolithic (PPN), i.e., the Pre-Pottery Neolithic A (PPNA; 9.500-8.700 BCE), and the Early and early Middle Pre-Pottery Neolithic B (EPPNB-MPPNB; 8.700-8.000 BCE). The nine hectare large mound is focal point of a newly inscribed UNESCO World Heritage Site. The eight monumental buildings so far discovered at Göbekli Tepe are labelled A through $\mathrm{H}$ in the order of their discovery. These buildings were multiphase structures with long biographies in excess of decades, perhaps even centuries [1,5-8]. Based on a presumed absence of domestic buildings and water sources, Göbekli Tepe was soon interpreted as a solely ritual site and that the associated demands on hunter-gatherer subsistence economies consequently triggered technological innovations, primarily the domestication of plants and animals [2,9-12]. At the time this hypothesis was ground-breaking in that it reversed previous opinions which saw domestication as the prerequiste for the subsequent emergence of religion. Meanwhile, recent excavations have relativized this statement. Not only is there now evidence for domestic occupations at the site from its earliest phases, it is likely that settlement continued unabated into the PPNB [1].

Currently, there is an imbalance between on-site archaeological investigations as described above and off-site studies dedicated to systematic geographical and geoarchaeological questions that are yet lacking for the environs of Göbekli Tepe. ${ }^{1}$ The integration of Göbekli Tepe in the broader landscape is a crucial step toward a better understanding of late hunter-gatherer lifeways prior to the emergence of morphologically domestic plant and animal species. In this contribution we present a first general environmental characterization of the site and its hinterland. We assess to what extent the present environmental characteristics are comparable to those of the Early Holocene, thus providing a starting point for later reconstructions of environmental perception and landscape creation in the PPN. This study is based on a literature review, map data and analyses of remote sensing data, including different digital terrain modeling approaches. Furthermore, it integrates the results of geomorphological mapping and extensive field-inspection.

\section{Overview of the Natural Characteristics in the Environs of Göbekli Tepe}

Göbekli Tepe is located about $12 \mathrm{~km}$ northeast of the modern city of Şanlıurfa. The Urfa region (Urfa Yöresi) is characterized by a nearly horizontal limestone formation that forms the Urfa plateau (Urfa Yayla). The research area is a highly homogeneous region which stretches from the northern arch of the Euphrates (turk. Fırat) in the north and west (Siverek and Birecik Çevresi) to the foot of the Karaca Dağ in the east, and up to Syrian-Turkish border in the south ([15,16]; Figure 1).

\subsection{Bedrock and Soils}

The area is characterized by various limestone and marl formations (Figure 2). The Tektek, Fatık, and Germuş Dağları (mountain ranges) —in the central part of the study area-are built up of shallow water limestones from the Neogene which feature abundant fractures and karst features [17]. Shallow calcisols with massive underlying calcretes developed in the mudflow deposits of the two fault sides (the Tektek and Fatık Dağları) belonging to the Akçakale-Harran graben [18].

\footnotetext{
1 Exceptions are $[13,14]$, though these were limited to conclusions based on pedogenic carbon analysis.
} 


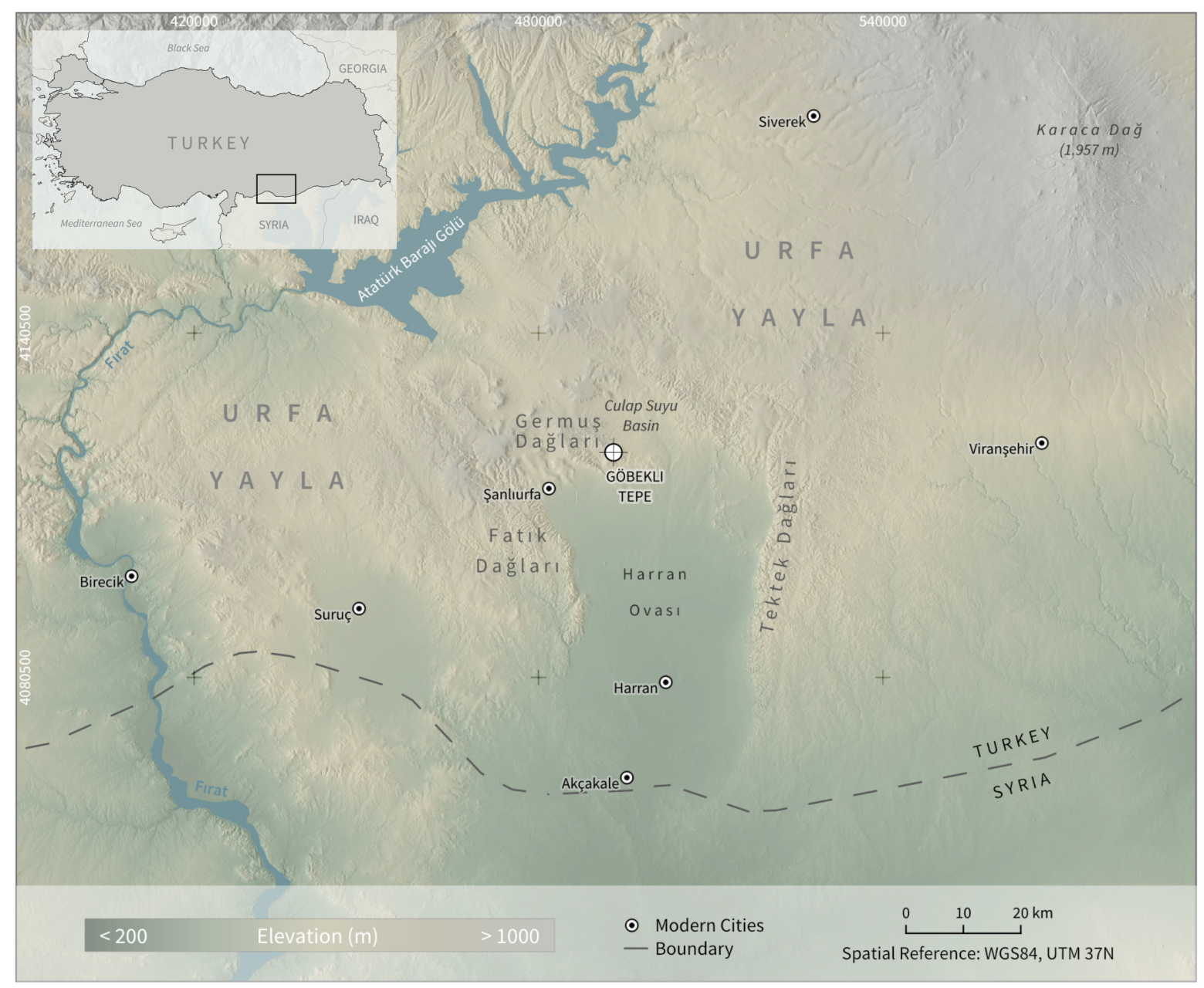

Figure 1. Overview map of the study area with main topographic features and sites as mentioned in the text (elevation based upon European Digital Elevation Model (EU-DEM), version 1.1, http: / / land.copernicus.eu/pan-european/satellite-derived-products/eu-dem/eu-dem-v1.1/view).

The surface deposits of the Akçakale-Harran Graben, which corresponds to the Harran Ovas1 (plain), are Pleistocene clays, sands, and gravels. These undifferentiated sediments cover limestone and marl deposits of several hundred meter thickness [19]. The most common soils of the Harran Ovası are vertisols with a well-developed Bss-horizon characterized by a smectite content of over $50 \%$ in its clay fraction [20].

North of Göbekli Tepe, Upper Cretaceous clastic limestone occurs that is superimposed by Upper Miocene basalt rocks. Basaltic covers are also present as residual patches in the immediate vicinity of Göbekli Tepe, as well as in the Fatık Dağları and in northern parts of the Tektek Dağları, upon which vertisols and cambisols developed [20]. The clay fraction of these soils shows particular features of transformation and neoformation from smectite to palygorskite or kaolinite-the former can be seen as an indicator for drier climatic conditions with limited processes of desilication, while the latter is indicative for a wetter climate [20]. 
(a) Chronostratigraphy

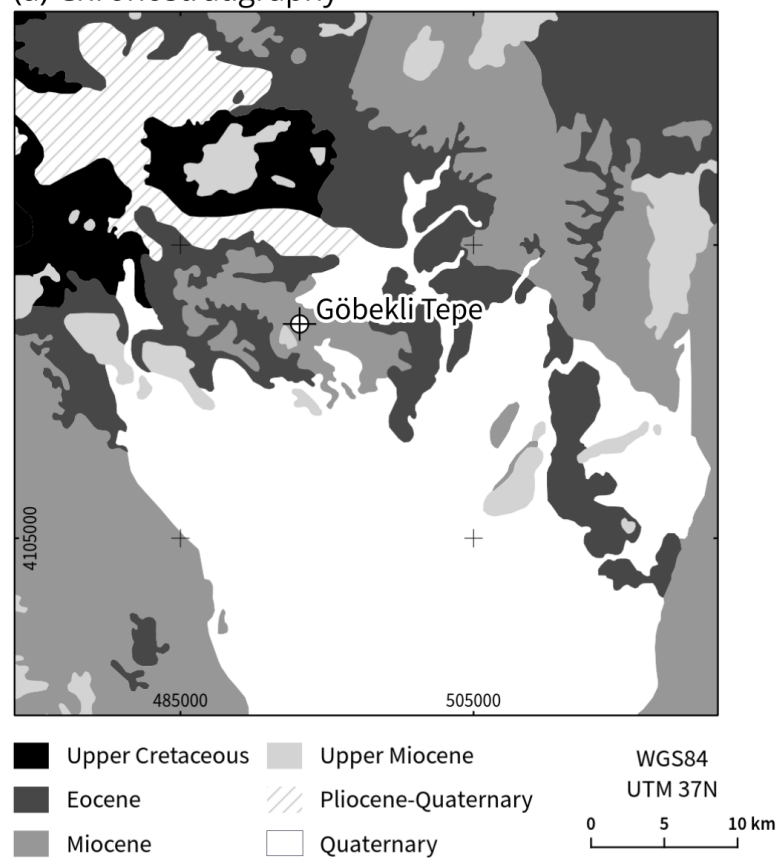

(b) Lithology

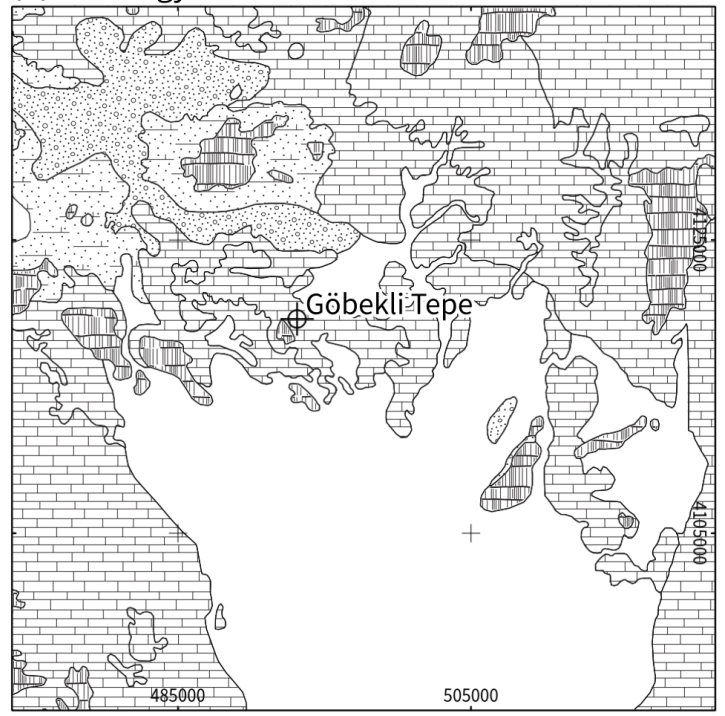

Basalt

Non graded terrigenous clastics

Carbonates and clastics Terrigenous clastics

Neritic Limestone $\quad \square$ Undifferentiated

Figure 2. Chronostratigraphy (a) and Lithology (b) in the environs of Göbekli Tepe (based on [21]).

\subsection{Climate}

Şanliurfa province is characterized by a semi-arid climate with dry hot summers (mean temperature in July: $30^{\circ} \mathrm{C}$ ) and cool wet winters (mean temperature in January: $4-5{ }^{\circ} \mathrm{C}$ ) and an annual average temperature of $18{ }^{\circ} \mathrm{C}$ (Figure 3). Reliable rainfall occurs in autumn, which can fall as snow in the winter months; the wet season ends in May. The Harran Ovası has a mean annual precipitation of $283 \mathrm{~mm}$, while mean annual evaporation can reach up to $1848 \mathrm{~mm}$ [19]. Orographic effects cause higher annual precipitation rates in the northern part of the province [22].

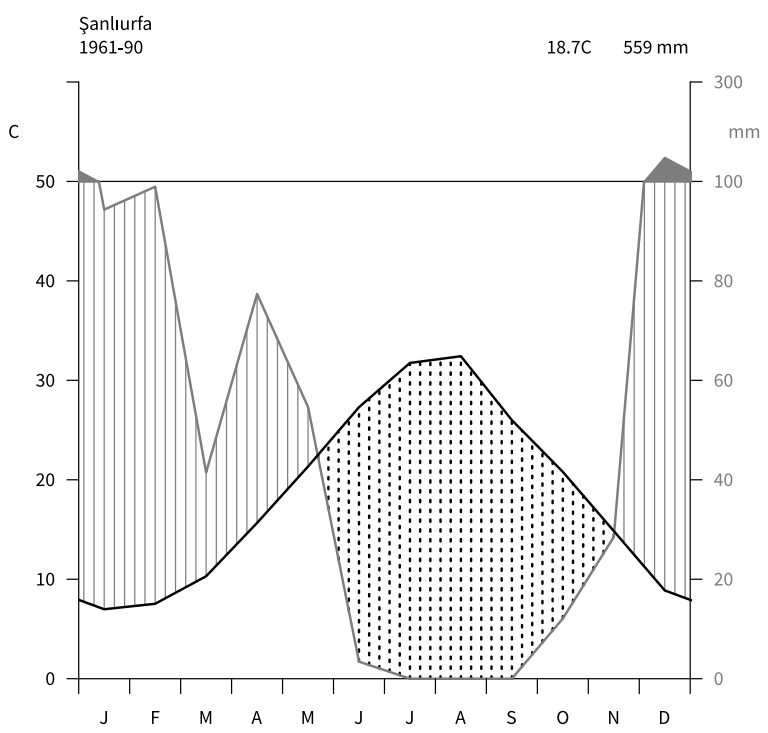

Figure 3. Climate diagram of Şanlıurfa. Arid conditions prevail during summer months (reference period: 1961-1990; data acquired from https:/ / climexp.knmi.nl/, referring to the World Meteorological Organization station Urfa, code: 17270 (based on [23])). 


\subsubsection{Model-Based Late Quaternary Climatic Development}

PMIP III climate model experiments enable the reconstruction of climatic characteristics in the wider study area for different time periods (Figure 4). The model results suggest that the area around Göbekli Tepe in the Last Glacial Maximum (21 ka BP) was characterized by a summer dry, cold climate (Dsa after Köppen-Geiger). Temperatures increased in the Holocene, leading to a temperate climate with hot and dry summers (Csa after Köppen-Geiger).

(a) Last Glacial Maximum

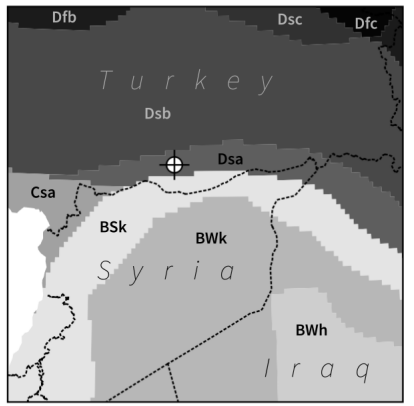

(d) Modern
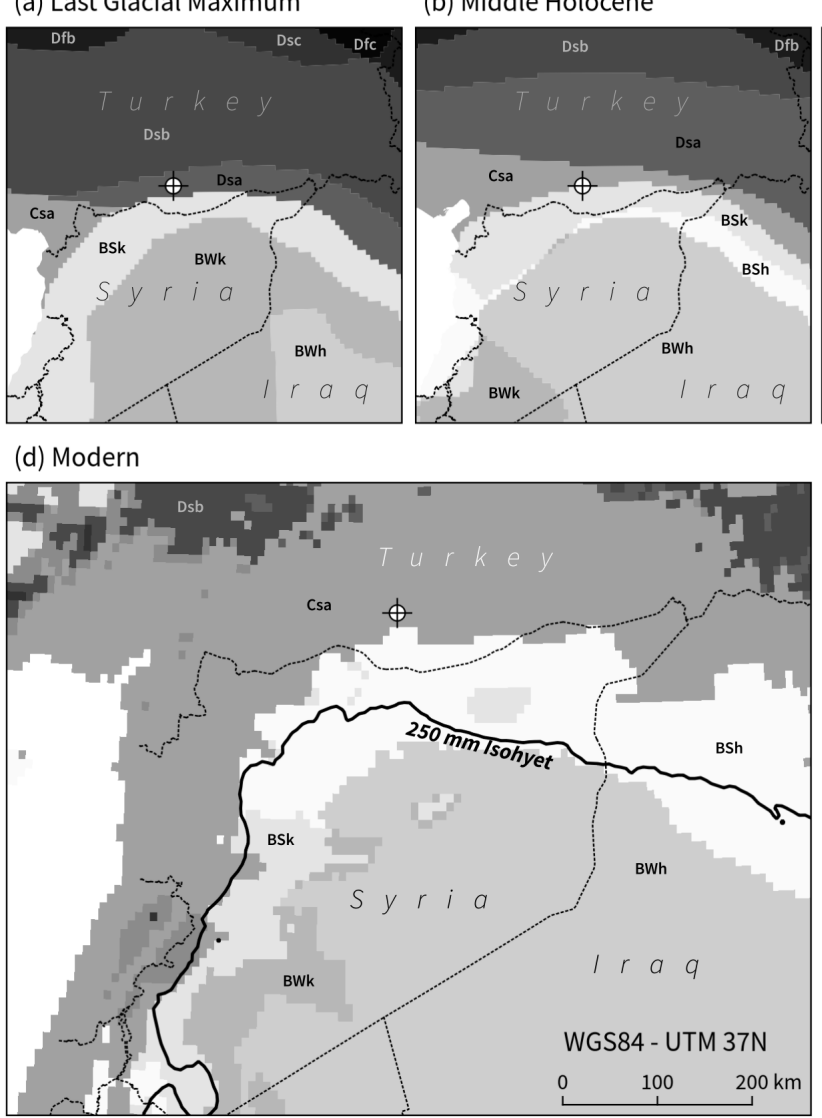

(c) Pre-Industrial

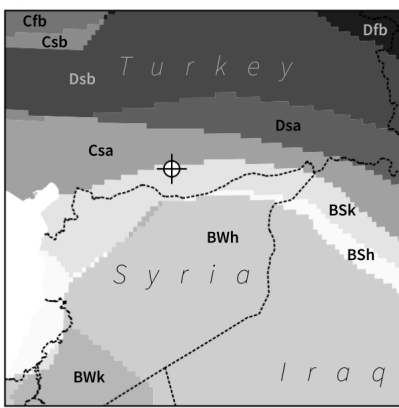

Climate

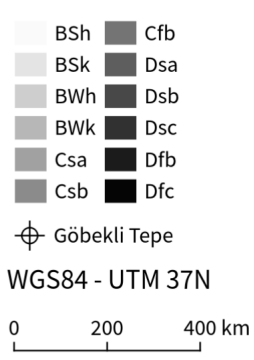

\begin{tabular}{lll} 
Key & Description & Criteria \\
\hline B & Arid & $M A P<10^{*} P_{\text {threshold }}$ \\
\hline$S$ & Steppe & $M A P \geq 5^{*} P_{\text {threshold }}$ \\
\hline W & Desert & $M A P<5^{*} P_{\text {threshold }}$ \\
\hline h Hot & $M A T \geq 18$ \\
\hline$k$ Cold & $M A T<18$
\end{tabular}

C Temperate $\quad T_{\text {hot }}>10 \& 0<T_{\text {cold }}<18$ s Dry Summer $\quad P_{\text {sdry }}<40 \& P_{\text {sdry }}<P_{\text {wwet }} / 3$ f Without dry season Not: $C s$ or $\mathrm{P}_{\text {wdry }}<\mathrm{P}_{\text {swet }} / 10$ a Hot Summer $\quad T_{\text {hot }} \geq 22$

b Warm Summer Not a \& $T_{\text {mon } 10} \geq 4$

\begin{tabular}{|c|c|c|}
\hline D & cold & $T_{\text {hot }}>10 \& 0<T_{\text {cold }} \leq 0$ \\
\hline $\mathrm{s}$ & Dry Summer & $P_{\text {sdry }}<40 \& P_{\text {sdry }}<P_{\text {wwet }} / 3$ \\
\hline$f$ & Without dry season & Not: Ds or $\mathrm{P}_{\text {wdr }}<\mathrm{P}_{\text {swet }} / 10$ \\
\hline a & Hot Summer & $T_{\text {hot }} \geq 22$ \\
\hline$b$ & Warm Summer & Not a \& $T_{\operatorname{mon} 10} \geq 4$ \\
\hline c & Cold Summer & Not $\mathrm{a}$ or $\mathrm{b}$ or $\mathrm{T}_{\text {cold }}<-38$ \\
\hline
\end{tabular}

Figure 4. Climatic characteristics in the wider surroundings of Göbekli Tepe during (a) Last Glacial Maximum (21 ka BP), (b) Middle Holocene (6 ka BP), (c) Pre-Industrial period (0 ka BP). Data are derived from climate model experiments (PMIP III), Köppen-Geiger classification conducted by Willmes et al. (see [24] for further details and raw data of classification); (d) Modern climate characteristics based on [25]; MAP = mean annual precipitation, $\mathrm{MAT}=$ mean annual temperature, $T_{\text {hot }}=$ temperature of the hottest month, $T_{\text {cold }}=$ temperature of the coldest month, $T_{\text {mon } 10}=$ number of months where the temperature is above $10^{\circ} \mathrm{C}, P_{s d r y}=$ precipitation of the driest month in summer, $P_{w d r y}=$ precipitation of the driest month in winter, $P_{\text {swet }}=$ precipitation of the wettest month in summer, $P_{\text {wwet }}=$ precipitation of the wettest month in winter, $P_{\text {threshold }}=$ varies according to the following rules (if $70 \%$ of MAP occurs in winter then $P_{\text {threshold }}=2 * M A T$, if $70 \%$ of MAP occurs in summer then $P_{\text {threshold }}=2 * M A T+28$, otherwise $P_{\text {threshold }}=2 * M A T+14$ ). Summer (winter) is defined as the warmer (cooler) six month period of October, November, December, January, February, March, and April, Mai, June, July, August, September (after [26]).

\subsubsection{Proxy-Based Late Quaternary Climatic Development}

Since paleoclimate proxies are still lacking for the immediate surroundings of Göbekli Tepe, reconstruction of Late Pleistocene to Early Holocene climate development are compiled for the Eastern Mediterranean region based on case studies (Table 1) and reviews [27-31]. Uncertainties relating to 
the absolute dating of paleoclimate records, climatic and environmental changes in the wider Eastern Mediterranean region appear to occur synchronously between c. 16-9 ka BP [28]. All proxy records indicate changed climatic conditions, however their timing and local occurrence is heterogeneous and show no general pattern.

The time period $25-17 \mathrm{ka}$ BP is characterized by colder temperatures $\left(12-16{ }^{\circ} \mathrm{C}\right)$ and less precipitation (300-450 mm) compared to present-day records [32]. Coldest (c. $\left.12^{\circ} \mathrm{C}\right)$ and driest (c. $250 \mathrm{~mm}$ ) conditions prevailed between c. $25-19 \mathrm{ka}$ BP [33], with increases in temperature $\left(14.5-18.5^{\circ} \mathrm{C}\right)$ and precipitation (375-540 $\mathrm{mm}$ ) becoming visible between 17-15 ka BP [32] but remaining below present-day conditions. A cold and relatively wet period during the Late Glacial (c. 17.3-14.8 ka BP) is evident in the data from Lake Hazar in central Anatolia [34], though records from Sofular Cave indicate cooler and drier conditions for northern Anatolia until $14.6 \mathrm{ka}$ BP [35].

At the onset of the Bølling-Allerød (c. $14.6 \mathrm{ka} \mathrm{BP}$ ) temperatures and moisture increased within a few decades to centuries (until $12.5 \mathrm{ka} \mathrm{BP}[34,35]$ ), thus corresponding with a period of maximum humidity during the Late Glacial (14.9-13.5 ka BP [36]). In the later part of the Bølling-Allerød (13.5-12.9 ka BP) conditions became drier [36]. The subsequent Younger Dryas coincides with highest levels of aridity (c. 12.5-11.7 ka BP) and is consistently referred to as a cool and extremely dry period [34-37]. In contrast, a general trend toward increasing precipitation $(680-850 \mathrm{~mm})$ is reported for central Israel in the period 12-10 ka BP [32].

The end of the Younger Dryas is marked by a rapid and substantial increase in temperature and moisture $[28,38]$. Until $9.5 \mathrm{ka}$ BP temperatures increased, though with gradually decreasing precipitation [34]. According to data from Lake Hazar, maximum precipitation between 10.1-9.3 ka BP coincides with the Early Holocene [36], while at Sofular Cave wettest conditions are dated slightly later at c. 9.6-5.4 ka BP [38]. This is in general agreement with data from central Israel showing increased precipitation (675-950 mm) between 10-7.0 ka BP, with a peak between 8.5-7.0 ka BP [33], also with the potential occurrence of heavy rainstorms throughout the year [32]. Although climate conditions in the Eastern Mediterranean during the Early Holocene were warmer and wetter than in the Late Glacial, short periods of rapid climate change have been identified in numerous paleoclimate proxy records (also at Lake Nar [37] and Soreq Cave [32,33]) at c. 10.2 ka BP, $9.3 \mathrm{ka}$ BP and 8.6 ka BP [27,29-31].

Table 1. Paleoclimatic and environmental proxies, their locations and regional context.

\begin{tabular}{|c|c|c|c|}
\hline Location & Region & Proxy & Reference \\
\hline Soreq Cave & C Israel & stable $\delta^{18} O$ and $\delta^{13} C$ isotopes from speleothems & {$[32,33,39]$} \\
\hline Lake Hazar & C Anatolia & $\mu$-XRF multi element data and $\delta^{18} \mathrm{O}$ and $\delta^{13} \mathrm{C}$ isotopes from ostracods & {$[34,36]$} \\
\hline Sofular Cave & N Anatolia & stable $\delta^{18} \mathrm{O}$ and $\delta^{13} \mathrm{C}$ isotopes and ${ }^{234} U /{ }^{238} U$ ratio from speleothems & {$[35,38]$} \\
\hline Lake Nar & C Anatolia & stable $\delta^{18} \mathrm{O}$ and $\delta^{13} \mathrm{C}$ isotopes and carbonate mineralogy from limnic sediments & [37] \\
\hline Lake Eski Acıgöl & SE Anatolia & multi-proxy & [40] \\
\hline
\end{tabular}

\subsection{Vegetation}

Steppe and arboreal vegetation with $C_{4}$ plants, a low plant density, and little soil microbial activity due to dry climatic conditions prevailed between $50.3 \mathrm{ka}$ BP and 14.6 ka BP [35]. The subsequent Bølling-Allerød, with its increasing temperatures and effective moisture, is characterized by a greater proportion of $C_{3}$ plants and higher soil productivity [35]. The dry and cold climatic conditions during the Younger Dryas again triggered a retreat of mesic forests and the spread of steppic vegetation [36]. Comparison of Lake Eski Acıgöl (SE Anatolia) and Lake Van (E Anatolia) records show a rapid switch from Artemisia-chenopod to grass steppe at the end of the Pleistocene, and the increase and subsequent decrease of Pistacia during the first half of the Holocene [40]. Rössner et al. [41] propose for the research area an oak decrease in the Younger Dryas, replaced by dense stands of annual grasses. However, a postulated renewed spread of oak woodland in the Early Holocene is not reflected in the available archaeobotanical data from Göbekli Tepe, where there are high ratios of grasses, pistachio and almond (cf. [42]). Grasses included cereals such as wild einkorn, wild wheat, and wild 
barley. Furthermore, 90\% of charcoal samples from Göbekli Tepe have been identified as pistachio and almond [42]. In summary, botanical remains indicate that a steppe vegetation with stands of pistachio and almond trees was characteristic of the landscape at Göbekli Tepe at the time of its settlement. This conclusion is further supported by archaeofaunal analyses which show high ratios of open grassland inhabitants (e.g., Ovis, Capra, Gazella and Equus) among recovered animal remains [43].

Non-arboreal taxa as well as mesic deciduous trees declined sharply in the Eastern Mediterranean during the climatic aridization after c. $6.5 \mathrm{ka}$ BP [40]. First human impact on vegetation becomes evident between c. 4.5-4.0 ka BP [40]. Today, Irano-Turanian steppic vegetation types such as Fabaceae, Asteraceae, and Poaceae members are widespread [44]. However, as a result of intensive cultivation and animal pasturing the potential natural vegetation in most parts of the region has disappeared [45], e.g., in the area of the Culap Suyu basin and the Harran Ovası (Figure 8d) it has been replaced by irrigation agriculture.

\section{Assessment of Geomorphodynamics and Landform Classification}

\subsection{Geomorphometric Analyses}

The existence time of relief forms and their spatial extent follows approximately a logarithmic distribution, i.e., large landforms persist for long periods of time, while small landforms are more transient [46]. Accordingly, the application of a modern digital elevation model provides insights into the general relief characteristics and process dynamics for Göbekli Tepe and its hinterland. However, small topographic features are not identifiable since these have been either destroyed by erosion or covered by sediments (Figure 5).

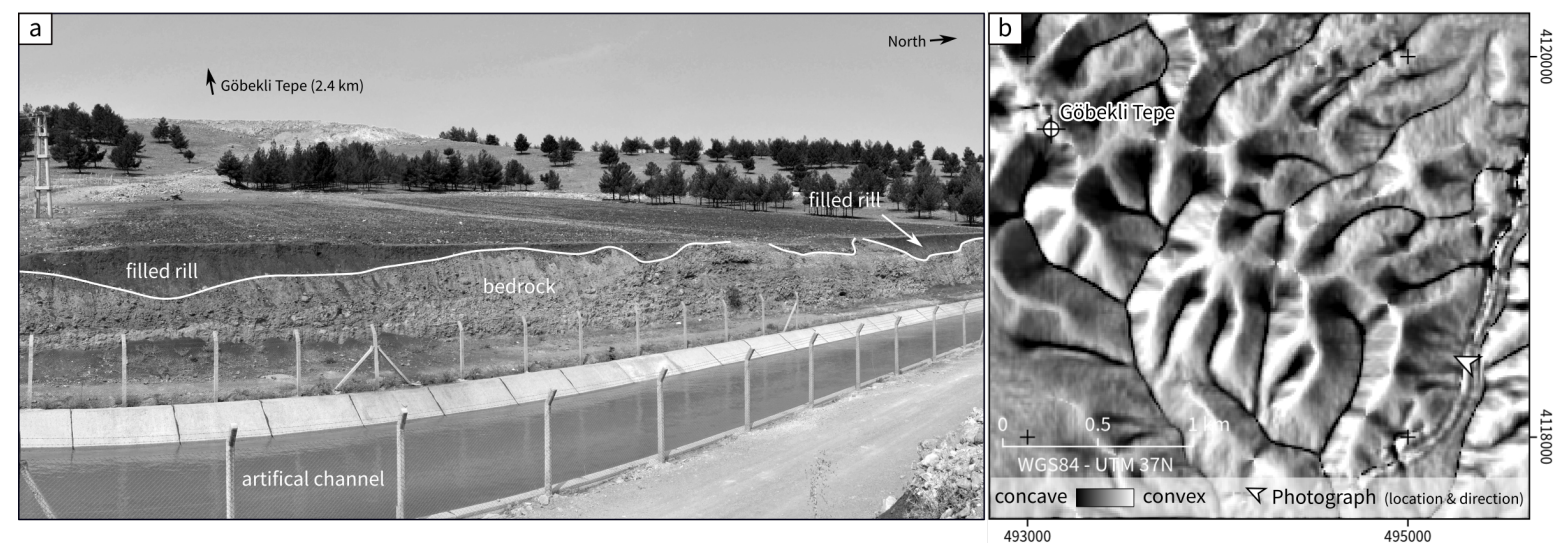

Figure 5. Small topographic features, like rills, that might have existed during time of occupation of Göbekli Tepe will be not visible utilizing modern surface information due to their short existence time; (a) Photograph showing sediment filled rills in the headwater area that were exposed by the construction of an irrigation channel; (b) Map of tangential curvature, showing the generally smooth charater of the slopes, with little traces of rills on the surface.

A digital elevation model (TanDEM-X, $12 \mathrm{~m}$ resolution) is used to derive geomorphometric parameters, each showing complementary features of general topographic characteristics and relief elements larger than rills or gullies (calculations undertaken with GRASS GIS [47]):

- Slope, a continuous parameter, is used to show the gradient of the site and its hinterland (Figure 6a). The highest gradients are mainly present in the areas of upper midslopes adjacent to the limestone plateaus. With the exception of the more gentle slopes in the area of the basalt plateau, southwest of Göbekli Tepe, the slopes in its immediate surroundings are very steep. The rolling hills are characterized by intermediate inclinations, and the undulating and flat plains towards the east and south show the lowest slope values (cf. Figures 6a and 8a). 
- Profile Curvature, a continuous parameter of surface curvature in the direction of gradient [48], is used to identify the nature of steps and breaks in topography e.g., between the plateaus and the lower lying slopes (Figure 6b). The extended plateau, upon which Göbekli Tepe is located, is separated from the slope by a pronounced convex break. The convexities decrease toward the rolling hills and pronounced convex breaks in slope are absent. High concavities are present along the drainage ways of the low order catchments surrounding Göbekli Tepe and in the basin to its west and diminish when approaching the flat plains surrounding the archaeological site (cf. Figures $6 \mathrm{~b}$ and $8 \mathrm{a}$ ).

- Topographic Index, a continuous parameter showing the liability of relief to concentrate water [49], is used to distinguish areas of more concentrated, linear runoff from areas with a more extensive and less distinct runoff (Figure 6c). It is evident that only the flat basalt plateau southwest of Göbekli Tepe, as well as the midstream-sections of the first-order streams of the Culap Suyu basin, show a tendency toward extensive converging flows. The limestone plateaus and the rolling hills, however, show strongly diverging flows (cf. Figures $6 \mathrm{c}$ and 8a).

- Geomorphons [50], a nominal parameter showing different landforms, is used to identify areas with similar geomorphometric characteristics (Figure 6d). The intense dissection of the limestone plateaus and the rolling hills is shown by the close proximity of the classes ridge and spur and the class valley. In contrast, in the direction the undulating plain of the Culap Suyu basin and the northern Harran Ovası, the distance between the classes ridge and spur and the class valley increases, thus indicating that the relief of the basin is less structured than the limestone plateaus and the rolling hills (cf. Figures $6 \mathrm{~d}$ and $8 \mathrm{a}$ ).

Since the area is characterized by poorly porous limestones with low infiltration capacity, precipitation often generates surface runoff which leads to erosion, an important factor in younger relief development. In order to identify areas most liable to changes in topography triggered by erosion and deposition, a Unit Stream Power Based Erosion Deposition model (USPED) is applied which combines the Universal Soil Loss Equation parameters with the upslope contributing area. Accordingly, the liability of the area to sediment flows is assessed (cf. [51,52]). Therefore, erosion and deposition is computed as change in sediment flow in the direction of steepest slope (Figure 7).

The required factors for the USPED model are created using GRASS GIS [47] and R [53]: ${ }^{2}$

- Slope length factor, i.e., a topographic factor mirroring the dependence of erosion on the length as well as the gradient of the slope, is derived from a digital elevation model.

- The soil erodibility is influenced by organic matter content, soil texture, its permeability and profile structure. Due to the absence of extensive and systematic soil survey, we link the soil erodibility to geological information (Section 2.1 and Figure 2). This is appropriate, since soil types in the area are strongly determined by bedrock properties. Soil texture characteristics are derived from representative, published soil profiles: It follows that Chromic Vertisol soil ([20], p. 173) is related to the geological unit alluvium (unit "undifferentiated" in Figure 2), Chromic Ochric Vertisol ([18], p. 114) is related to the basalt regions, Petric calcisol chromic ([18], p. 151) is related to limestone areas, and Cambisol, i.e., Karataş soils ([18], p. 114), is related to terrigenous clastics.

- Since spatially and temporally high-resolution weather and climate information are not available, Rainfall erositivity, i.e., the kinetic energy of rainfall, is approximated based on climate information from Şanliurfa weather station [23] and a modified Fournier's index [54].

- The other factors of the erosion model require information on Land-use and soil conversation measures. They are omitted owing to lack of data.

2 Of course, the model can only be considered as rough estimation since it utilizes modern data as well as simplifying assumptions concerning substrate and climatic information. 

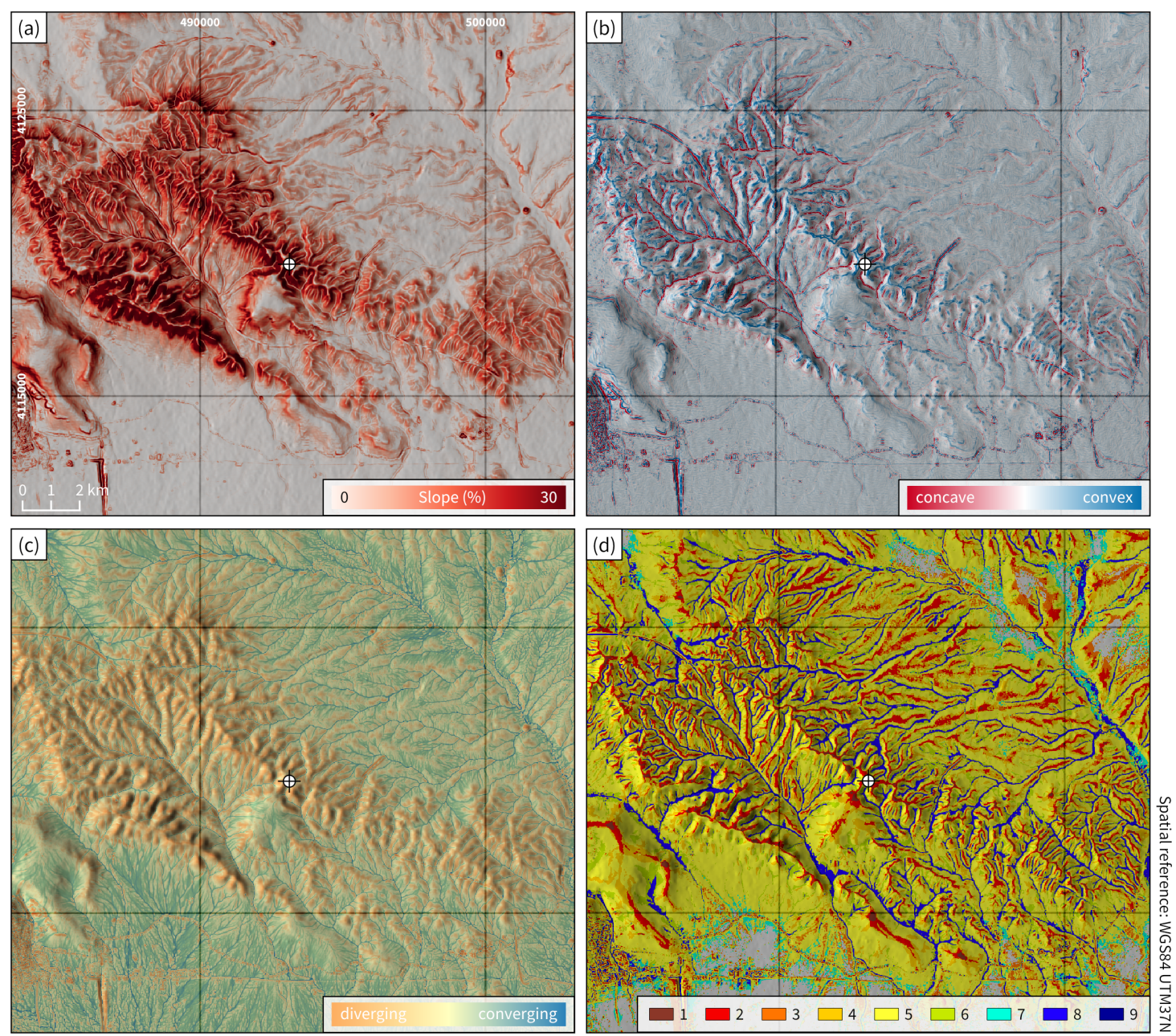

Figure 6. Geomorphometric parameter raster derived from digital elevation model: (a) Slope (in percent); (b) profile curvature; (c) Topographic Index; (d) Geomorphons, numbers correspond to: 1-summit, 2-ridge, 3-shoulder, 4-spur, 5-slope, 6-hollow, 7-footslope, 8-valley, 9-depression.

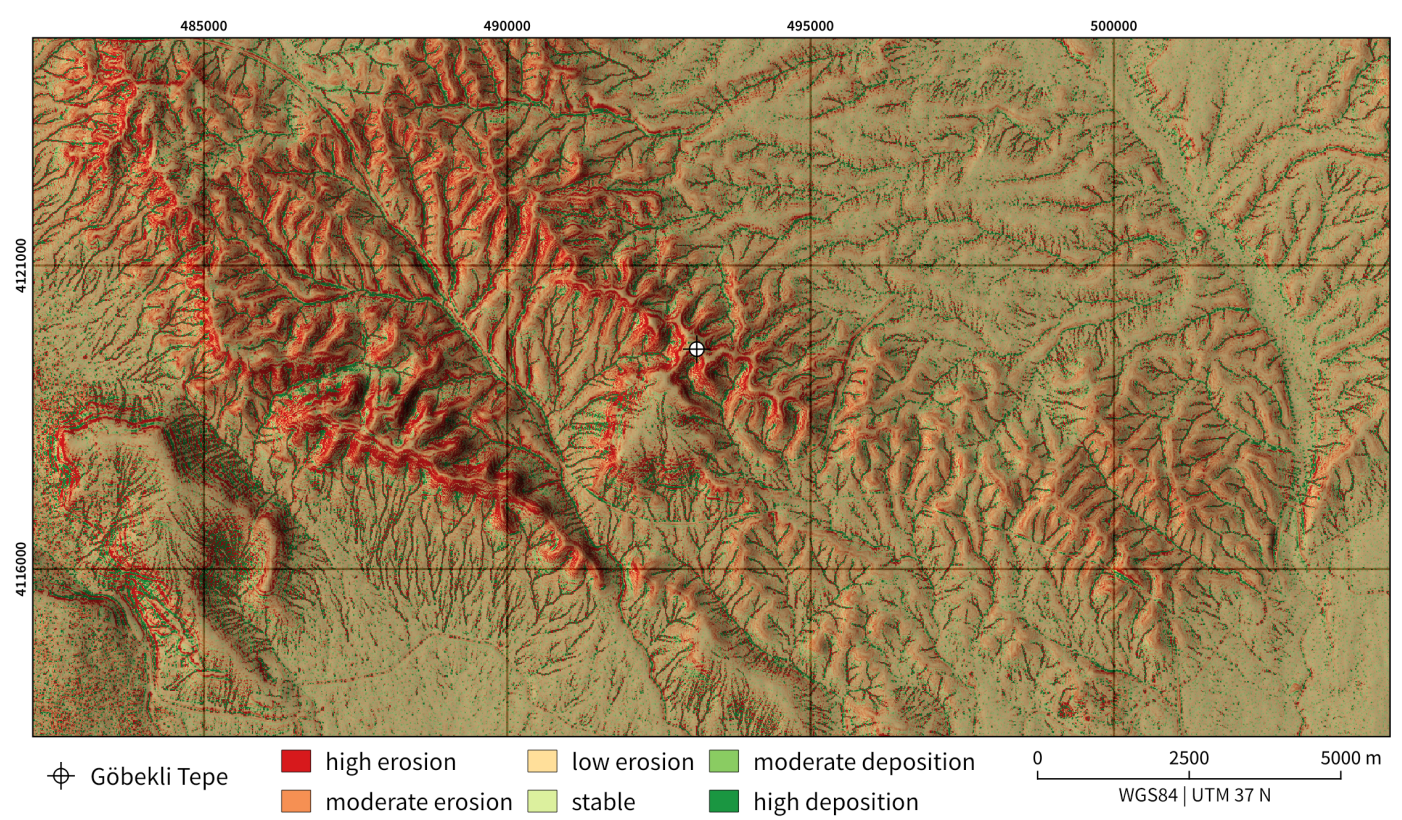

Figure 7. Sediment-sinks and sediment-sources at Göbekli Tepe and in its hinterland as derived from a USPED model. 


\subsection{Geomorphological Mapping}

The geomorphological characteristics of Göbekli Tepe and its hinterland are assessed using detailed geomorphological mapping (after $[55,56]$ ) for the close vicinity of the site (approx. $4 \mathrm{~km}$ radius), combined with extensive field-inspection and photo documentation for the wider hinterland (approx. $12 \mathrm{~km}$ radius). The detailed geomorphological field maps were digitized and cross-checked, generalized, and extrapolated on the basis of high resolution satellite imagery $(<1 \mathrm{~m}$ resolution; DigitalGlobe, Inc., maps.google.com, last accessed 5 October 2018) to provide an overview map of the general geomorphological units (Figure 8a). The geomorphological units scree slopes and undulating plains were combined with the terrain form valley from the computed geomorphons and sedimentological field data to provide an overview of the typical locations of the dominating sediments (Figure 8a).

\subsection{Landform Characterization}

The six general landform units identified in the environs of Göbekli Tepe are: limestone plateaus, basalt plateaus, scree slopes, undulating plains, flat plains, and alluvial plains (Figure 8a).

The limestone plateaus are characterized as outcropping bedded limestone usually showing mayor scarps at the shoulders and located in upper midslope positions. The mainly flat-lying limestone plateau areas are mostly lacking sediments [22]; locally they show a cover of up to boulder-sized gravels and patches of a thin soil layer (Figure 8b; [57]). According to the erosion-deposition model these areas show low erosion liability or stable conditions (Figure 7). Downslope of the mayor scarps, usually at the upper midslopes, the modeled erosion liability is highest (Figure 7). These areas are mostly covered with gravels of up to boulder size and largely lack a cover of fine sediments (Figure $8 b$ ). The sharp forms that characterize the limestone plateaus are not present in the basalt plateau areas where much smoother forms dominate (Figure 8a) and largely stable conditions prevail (Figure 7). The basalt plateaus are densly covered with up to boulder-sized gravels and usually show a considerable soil cover that is used for arable farming [22] after surface clearance (Figure 8c).

The scree slope unit comprises the midslope sections adjacent to the plateaus and the rolling limestone hills (Figure 8a). These areas are characterized by sediment covered slopes (Figure 8b). Erosion liability is usually high to moderate and locally a moderate to high deposition liability occurs (Figure 7). The sediments that are present on the scree slopes are dominated by gravels with a considerable amount of fine sediments (Figure $8 b$ ) wherein soil formation occurs [22].

The footslopes are characterized by the deposition of slope sediments (Figure 8a) that frequently exhibit particular depositional structures such as clasts with downslope-dipping long axes. Along the thalweg the slope sediments are mostly dissected by recurring concentrated overland flows forming distinct steps. In the erosion-deposition model these conditions are reflected in the frequencies of adjacent (i.e., in neighboring cells) high erosion and high deposition areas in the thalwegs of the valleys (Figure 7).

The same pattern is also present further downslope in the areas of the undulating plains (Figure 7), but with a clear difference in depositional conditions. The sediments along these thalwegs are characterized by a distinct division of well rounded, fluvially deposited gravels that partially show normal grading or imbrication and locally redistributed slope sediments (Figure 8a). Soils are usually thicker than those found on the scree slopes or at footslope positions [22]. The unit of the undulating plains covers the piedmont area of the rolling hills, i.e., most of the surface of the Culap Suyu basin and the northern part of the Harran Ovası (Figure 8a,d). Further to the south, the Harran Ovası becomes increasingly flat (Figure 8a).

In the alluvial plain of the north-south oriented Culap Suyu river, which is located east of Göbekli Tepe, Late Pleistocene and Holocene alluvial loams are accumulated [22]. In the area of the Culap Suyu basin the alluvial plain tends to be delimited by a marked step toward the undulating plain (Figure 8d). This step increasingly vanishes in the area of the flat plain of the northern Harran Ovasi. Here, the alluvial plain also widens considerably (Figure 8a). 

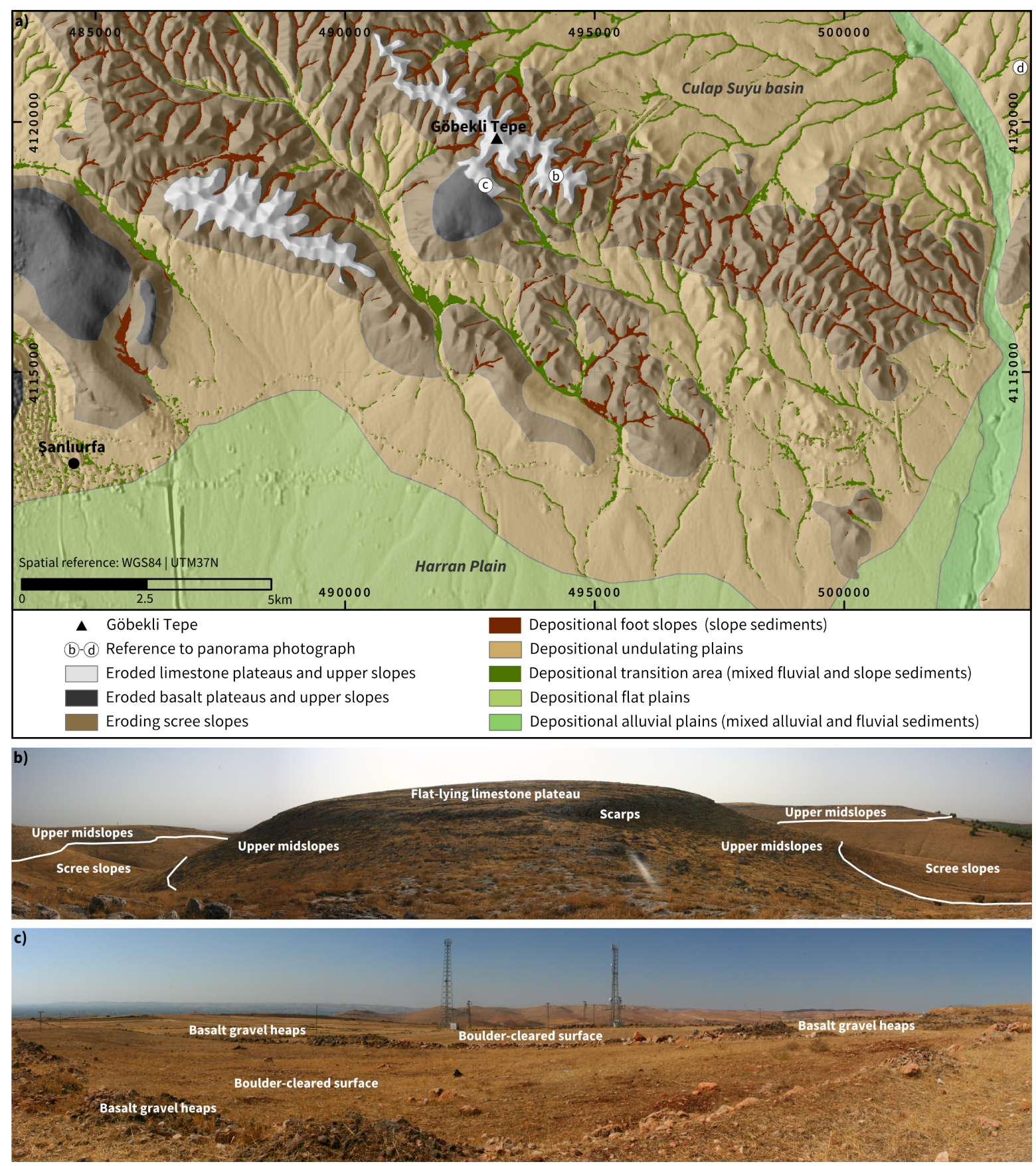

d)

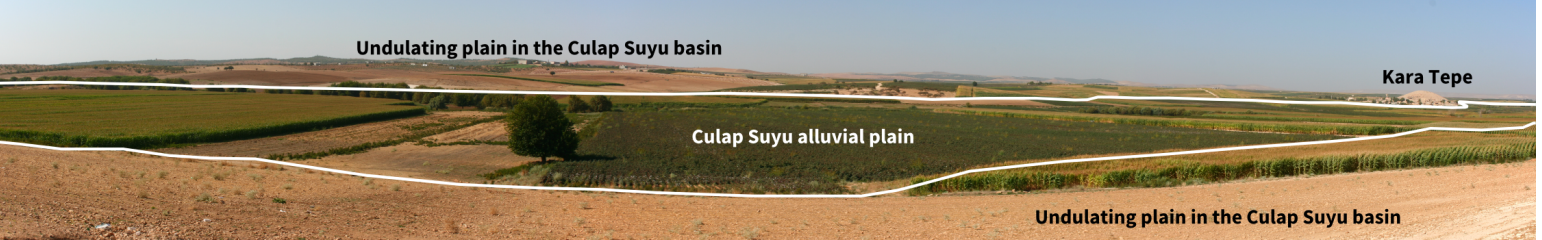

Figure 8. (a) Geomorphological overview map of the wider surroundings of Göbekli Tepe, i.e., the northern Harran Ovası and the southern Culap Suyu basin with photo locations of panorama pictures (b-d). (b) Panorama photograph of the limestone plateau, the areas of the upper midslopes and the adjacent scree slopes. (c) Panorama photograph of the basalt plateau southwest of Göbekli Tepe showing the boulder-cleared surface and the basalt gravel heaps. (d) Panorama photograph of the Culap Suyu alluvial plain and the adjacent undulating plains in the Culap Suyu basin. 


\section{A Short Description of Göbekli Tepe's Environment}

This review of natural environmental conditions and the analysis of local geomorphodynamics not only permits a more comprehensive description of the location of Göbekli Tepe, it also shows whether this location was distinct in terms of its environmental signature. Based on currently available data it cannot be adequately assessed whether the present-day natural environmental conditions resemble those prevailing at the time of settlement activity at Göbekli Tepe (11.5-10 ka BP); nevertheless, different hypotheses can be postulated:

- We consider that the general characteristics of bedrock and topography around the site are currently similar to those in the Early Holocene, though changes in the course of the last eleven millennia cannot be ruled out.

- The climate conditions have indeed changed in the last c. $25 \mathrm{ka}$ albeit that the magnitude of variation strongly depends on the datasets used for reconstruction (cf. Sections 2.2.1 and 2.2.2). Generally, paleoclimate proxies suggest that substantially higher precipitation and temperatures prevailed during the Early Holocene in the Eastern Mediterranean [28,32-34,36,37]. However, in the absence of reliable paleoclimate archives from the research area these results cannot be elaborated further, nor can it be verified whether precipitation rates also increased in the environs of Göbekli Tepe. Nevertheless, the model-based and the proxy-based reconstructions show that neither glacial nor periglacial conditions have prevailed in the region since at least $\mathrm{c}$. $25 \mathrm{ka} \mathrm{BP}$, as this would have hampered chemical weathering, soil formation and the development of a steppe or forest-steppe vegetation. Therefore, we can assume that at least c. 15 ka prior to the establishment of Göbekli Tepe, the climatic conditions more or less continuously fostered chemical weathering, soil formation, and the establishment of a vegetation cover.

- Accordingly, we assume that the limestone plateaus and upper midslopes were covered by loose material, created by in situ weathered bedrock and characterized by developed soils-fixed by the roots of the vegetation. This assumption rests on the evidence that agricultural practices such as arable farming and animal husbandry are not attested at Göbekli Tepe and it can be assumed that potential disturbances of the persisting steppe-forest [43] were minimal. In consequence, soil erosion and sediment redistribution triggered by human influences were largely absent. Furthermore sediment transport to the foot slopes, alluvial plains, and streams would have been negligible. The loose material which we expect to have formed on the plateaus and the sediments that we expect to have accumulated on the slopes in the Late Pleistocene were likely eroded during the Holocene due to varying climatic conditions, human impact, or-most likely-a combination of both. Indications that human activities fostered soil erosion and sediment redistribution are known from archaeological sites in the area at least since the Bronze Age (cf. [22,45,57]). Today, soil erosion is largely absent at the upper midslopes due to lacking soil cover (cf. Figure 8b) and erosion features only occasionally occur mid- and downslope. Rills at the footslopes that are incised in the bedrock are sediment-filled today and prove that linear erosion took place at a yet unknown time (cf. Figure 5). One possible interpretation of this seemingly contradictory observation is a scenario in which erosion and deposition alternate, depending on the general climatic conditions.

- The present-day climatic conditions would allow a vegetation cover that is comparable to the one that existed during the settlement period of Göbekli Tepe [42,43]; however, past and present land degradation and modern agricultural practices have prevented the development of this potential natural vegetation cover [45]. Animal husbandry, mainly sheep and goat pasture, prohibits the re-establishment of a steppe like vegetation, especially grasses; arable farming prohibits the re-establishment of a light steppe "forest"; arboriculture, e.g., olive plantations and afforestation, prevents the formation of natural steppe. Changes in the hydrological system, as most obvious in the Harran Ovası and the Culap Suyu basin, in combination with irrigation measures constitute 
an entirely human-managed agro-landscape that has nothing in common with conditions that prevailed 100 or 10,000 years ago.

Hence, locally the environmental characteristics around Göbekli Tepe may have changed considerably in the course of the Late Pleistocene and Holocene. The degree to which such changes are of importance for the understanding and interpretation of the archaeological site is the objective of future research.

\section{Conclusions}

This literature review combined with the results of remote sensing data, digital terrain modeling, and geomorphological field work represents the first systematic compilation of environmental data in the surroundings of UNESCO World Heritage Site Göbekli Tepe. Based on this synthesis of the currently available data, complex landscape dynamics with non-linear consequences on local and regional scales are attested.

Although the bedrock has remained unchanged at least since the Early Holocene, soil cover and vegetation have been, among other things, influenced by human activities. Earliest indications for soil erosion are known from the Bronze Age, however, anthropogenic impacts should not be ruled out for earlier periods, including the Late Paleolithic and the Neolithic. Accordingly, further field studies and research focusing on the Late Pleistocene and Early Holocene are crucial not only in the vicinity of Göbekli Tepe, but also in its wider environs.

In the light of climate and environmental change to have occurred in the last twelve millennia, a continuous integration of disciplinary results and interdisciplinary research is necessary in order to provide a more profound understanding of the site and its landscape integration. The present compilation of environmental data forms the basis for further research on diachronic trends of sediment dynamics and on changes in landscape perception and creation among prehistoric communities.

Author Contributions: Conceptualization: D.K., R.B., M.N.; Geomorphometric analysis and modeling: D.K.; Geomorphological analysis: M.N.; Figures and maps: D.K., R.B., M.N.; Writing—original draft: D.K., R.B., M.N.; Writing-reviewing draft: D.K., R.B., M.N., B.S., L.C.; Revise: D.K., R.B., M.N.; Funding Acquisition: B.S., L.C., D.K.

Funding: This research was funded by: Deutsche Forschungsgemeinschaft (DFG, German Research Foundation) Projekt number 165831460 (The Prehistoric societies of Upper Mesopotamia and their subsistence), 2901391021 (Collaborative Research Center 1266 "Scales of Transformation").

Acknowledgments: We wish to thank the General Directorate of Cultural Assets and Museums, Ministry of Culture and Tourism of Turkey and the Şanlıurfa Museum for making research possible. We are grateful to three anonymous reviewers whose comments helped to improve this paper.

Conflicts of Interest: The authors declare no conflict of interest.

\section{References}

1. Clare, L.; Kinzel, M.; Sönmez, D.; Uludă̆, C. Göbekli Tepe: UNESCO Dünya Miras Alanı ve Değişen Yaklaşımlar. Mimarlk 2019, 405, 14-18.

2. Schmidt, K. Göbekli Tepe: A Neolithic Site in Southeastern Anatolia. In The Oxford Handbook of Ancient Anatolia (10.000-323 B.C.E.); Steadman, S., McMahon, G., Eds.; Oxford University Press: Oxford, UK, 2011.

3. Schmidt, K. Göbekli Tepe. In The Neolithic in Turkey: New Excavations \& New Research, 3rd ed.; Başgelen, N., Ozdoğan, M., Kuniholm, P.I., Eds.; Archaeology \& Art Publications: Galatasaray, İstanbul, 2011; Volume 2, pp. 41-83.

4. Benedict, P.; Çambel, H.; Braidwood, R.J. Survey Work in Southeastern Anatolia. In Prehistoric Research in Southeastern Anatolia 1; Istanbul Faculty of Letters No. 2589; Istanbul Faculty: Istanbul, Turkey, 1980; pp. 150-191.

5. Kinzel, M.; Duru, G.; Barański, M. Modify to Last-A Neolithic Perspective on Rebuilding and Continuation. In Umgebaut: DiskAB13; Wulf-Rheidt, U., Piesker, K., Zink, S., Eds.; Schnell \& Steiner: Regensburg, Germany, in press. 
6. Kurapkat, D. Frühneolithische Sondergebäude auf dem Göbekli Tepe in Obermesopotamien und Vergleichbare Bauten in Vorderasien. Ph.D. Thesis, Technical University Berlin, Berlin, Germany, 2015.

7. Piesker, K. Göbekli Tepe-Bauforschung in den Anlagen C und E in den Jahren 2010-2012. Zeitschrift für Orient-Archäologie 2014, 7, 14-54.

8. Kurapkat, D. Die Frühneolithischen Bauanlagen auf dem Göbekli Tepe in Obermesopotamien (Südosttürkei). Eine Darstellung des Untersuchungsstands der Baubefunde. In Bericht über die 42. Tagung für Ausgrabungswissenschaft und Bauforschung: Vom 08. bis 12. Mai 2002 in München; Vereinigung für baugeschichtliche Forschung Koldewey-Gesellschaft, Ed.; Habelt: Bonn, Germany, 2004; pp. 256-267.

9. Schmidt, K. Sie bauten die ersten Tempel. Das rätselhafte Heiligtum der Steinzeitjäger; C.H. Beck: München, Germany, 2006.

10. Schmidt, K. Göbekli Tepe, Southeastern Turkey: A Preliminary Report on the 1995-1999 Excavations. Paléorient 2001, 26, 45-54. [CrossRef]

11. Schmidt, K. Zuerst kam der Tempel, dann die Stadt. Vorläufiger Bericht zu den Grabungen Am Göbeki Tepe und am Gürçutepe 1995-1999. Istanbuler Mitteilungen 2000, 50, 5-41.

12. Schmidt, K. Frühneolithische Tempel. Ein Forschungsbericht zum Präkeramischen Neolithikum Obermesopotamiens. Mitteilungen der Deutschen Orientgesellschaft zu Berlin 1998, 130, 17-49.

13. Pustovoytov, K.; Schmidt, K.; Taubald, H. Evidence for Holocene Environmental Changes in the Northern Fertile Crescent Provided by Pedogenic Carbonate Coatings. Quat. Res. 2007, 67, 315-327. [CrossRef]

14. Pustovoytov, K. Soils and Soil Sediments at Göbekli Tepe, Southeastern Turkey: A Preliminary Report. Geoarchaeology 2006, 21, 699-719. [CrossRef]

15. Erol, O. Die Naturräumliche Gliederung der Türkei. In Beihefte zum Tübinger Atlas des Vorderen Orients: Naturwissenschaften; Vol. Ausgabe 13; L. Reichert: Wiesbaden, Germany, 1983.

16. Erol, O. Türkei. Naturräumliche Gliederung (Ostteil); A-VII-02; Sonderforschungsbereich 19 “Tübinger Atlas des Vorderen Orients (TAVO)" der Universität Tübingen; Reichert: Wiesbaden, Germany, 1982.

17. Seyrek, A.; Yeşilnacar, M.I.; Aydemir, S.; Demir, T. Harran Ovasında yer alan Ortaören çökme çukurunun oluşumu ve pedo-jeolojik karakteristikleri. Marmara Coğrafya Dergisi 2003, Sayı 7, 108-125.

18. Akça, E.; Aydemir, S.; Kadir, S.; Eren, M.; Zucca, C.; Günal, H.; Previtali, F.; Zdruli, P.; Çilek, A.; Budak, M.; et al. Calcisols and Leptosols. In The Soils of Turkey; Kapur, S., Akça, E., Günal, H., Eds.; Springer: Cham, Switzerland, 2018; pp. 139-167. [CrossRef]

19. Yesilnacar, M.I.; Yenigun, I. Effect of Irrigation on a Deep Aquifer: A Case Study from the Semi-Arid Harran Plain, GAP Project, Turkey. Bull. Eng. Geol. Environ. 2011, 70, 213-221. [CrossRef]

20. Özcan, H.; Aydemir, S.; Çullu, M.A.; Günal, H.; Eren, M.; Kadir, S.; Ekinci, H.; Everest, T.; Sungur, A.; FitzPatrick, E.A. Vertisols. In The Soils of Turkey; Kapur, S., Akça, E., Günal, H., Eds.; Springer: Cham, Switzerland, 2018; pp. 169-206. [CrossRef]

21. General Directorate of Mineral Research and Exploration. Geological Map of Turkey, 1:500000; General Directorate of Mineral Research and Exploration: Ankara, Turkey, 2002.

22. Wilkinson, T.J. Town and Country in Southeastern Anatolia; Oriental Institute of the University of Chicago: Chicago, IL, USA, 1990.

23. Lawrimore, J.H.; Menne, M.J.; Gleason, B.E.; Williams, C.N.; Wuertz, D.B.; Vose, R.S.; Rennie, J. An Overview of the Global Historical Climatology Network Monthly Mean Temperature Data Set, Version 3. J. Geophys. Res. 2011, 116. [CrossRef]

24. Willmes, C.; Becker, D.; Brocks, S.; Hütt, C.; Bareth, G. High Resolution Köppen-Geiger Classifications of Paleoclimate Simulations. Trans. GIS 2017, 21, 57-73. [CrossRef]

25. Kottek, M.; Grieser, J.; Beck, C.; Rudolf, B.; Rubel, F. World Map of the Köppen-Geiger Climate Classification Updated. Meteorol. Z. 2006, 15, 259-263. [CrossRef]

26. Peel, M.C.; Finlayson, B.L.; McMahon, T.A. Updated World Map of the Köppen-Geiger Climate Classification. Hydrol. Earth Syst. Sci. 2007, 11, 1633-1644. [CrossRef]

27. Rohling, E.J.; Marino, G.; Grant, K.M.; Mayewski, P.A.; Weninger, B. A Model for Archaeologically Relevant Holocene Climate Impacts in the Aegean-Levantine Region (Easternmost Mediterranean). Quat. Sci. Rev. 2019, 208, 38-53. [CrossRef]

28. Roberts, N.; Woodbridge, J.; Bevan, A.; Palmisano, A.; Shennan, S.; Asouti, E. Human Responses and Non-Responses to Climatic Variations during the Last Glacial-Interglacial Transition in the Eastern Mediterranean. Quat. Sci. Rev. 2018, 184, 47-67. [CrossRef] 
29. Clare, L. Culture Change and Continuity in the Eastern Mediterranean during Rapid Climate Change: Assessing Impacts of a Little Ice Age in the 7th Millennium calBC; Number 7 in Kölner Studien Zur Prähistorischen Archäologie; Verlag Marie Leidorf: Rahden/Westf, Germany, 2016.

30. Weninger, B.; Clare, L.; Gerritsen, F.; Horejs, B.; Krauß, R.; Linstädter, J.; Özbal, R.; Rohling, E.J. Neolithisation of the Aegean and Southeast Europe during the 6600-6000 calBC Period of Rapid Climate Change. Doc. Praehist. 2014, 41, 1-31. [CrossRef]

31. Weninger, B.; Alram-Stern, E.; Bauer, E.; Clare, L.; Danzeglocke, U.; Jöris, O.; Kubatzki, C.; Rollefson, G.; Todorova, H.; van Andel, T. Climate Forcing Due to the 8200 Cal Yr BP Event Observed at Early Neolithic Sites in the Eastern Mediterranean. Quat. Res. 2006, 66, 401-420. [CrossRef]

32. Bar-Matthews, M.; Ayalon, A.; Kaufman, A. Late Quaternary Paleoclimate in the Eastern Mediterranean Region from Stable Isotope Analysis of Speleothems at Soreq Cave, Israel. Quat. Res. 1997, 47, 155-168. [CrossRef]

33. Bar-Matthews, M.; Ayalon, A.; Kaufman, A.; Wasserburg, G.J. The Eastern Mediterranean Paleoclimate as a Reflection of Regional Events: Soreq Cave, Israel. Earth Planet. Sci. Lett. 1999, 166, 85-95. [CrossRef]

34. Ön, Z.B.; Akçer-Ön, S.; Özeren, M.S.; Eriş, K.K.; Greaves, A.M.; Çağatay, M.N. Climate Proxies for the Last 17.3 Ka from Lake Hazar (Eastern Anatolia), Extracted by Independent Component Analysis of $\mu$-XRF Data. Quat. Int. 2018, 486, 17-28. [CrossRef]

35. Fleitmann, D.; Cheng, H.; Badertscher, S.; Edwards, R.L.; Mudelsee, M.; Göktürk, O.M.; Fankhauser, A.; Pickering, R.; Raible, C.C.; Matter, A.; et al. Timing and Climatic Impact of Greenland Interstadials Recorded in Stalagmites from Northern Turkey. Geophys. Res. Lett. 2009, 36. [CrossRef]

36. Eriş, K.K.; Ön, S.A.; Çağatay, M.N.; Ülgen, U.B.; Ön, Z.B.; Gürocak, Z.; Nagihan Arslan, T.; Akkoca, D.B.; Damc1, E.; İnceöz, M.; et al. Late Pleistocene to Holocene Paleoenvironmental Evolution of Lake Hazar, Eastern Anatolia, Turkey. Quat. Int. 2018, 486, 4-16. [CrossRef]

37. Dean, J.R.; Jones, M.D.; Leng, M.J.; Noble, S.R.; Metcalfe, S.E.; Sloane, H.J.; Sahy, D.; Eastwood, W.J.; Roberts, C.N. Eastern Mediterranean Hydroclimate over the Late Glacial and Holocene, Reconstructed from the Sediments of Nar Lake, Central Turkey, Using Stable Isotopes and Carbonate Mineralogy. Quat. Sci. Rev. 2015, 124, 162-174. [CrossRef]

38. Göktürk, O.M.; Fleitmann, D.; Badertscher, S.; Cheng, H.; Edwards, R.L.; Leuenberger, M.; Fankhauser, A.; Tüysüz, O.; Kramers, J. Climate on the Southern Black Sea Coast during the Holocene: Implications from the Sofular Cave Record. Quat. Sci. Rev. 2011, 30, 2433-2445. [CrossRef]

39. Bar-Matthews, M.; Ayalon, A. Mid-Holocene Climate Variations Revealed by High-Resolution Speleothem Records from Soreq Cave, Israel and Their Correlation with Cultural Changes. Holocene 2011, 21, 163-171. [CrossRef]

40. Roberts, N.; Reed, J.M.; Leng, M.J.; Kuzucuoğlu, C.; Fontugne, M.; Bertaux, J.; Woldring, H.; Bottema, S.; Black, S.; Hunt, E.; et al. The Tempo of Holocene Climatic Change in the Eastern Mediterranean Region: New High-Resolution Crater-Lake Sediment Data from Central Turkey. Holocene 2001, 11, 721-736. [CrossRef]

41. Rössner, C.; Deckers, K.; Benz, M.; Özkaya, V.; Riehl, S. Subsistence Strategies and Vegetation Development at Aceramic Neolithic Körtik Tepe, Southeastern Anatolia, Turkey. Veg. Hist. Archaeobot. 2018, 27, 15-29. [CrossRef]

42. Neef, R. Overlooking the Steppe-Forest: A Preliminary Report on the Botanical Remains from Early Neolithic Göbekli Tepe (Southeastern Turkey). Neo-Lithics 2003, 2, 13-16.

43. Peters, J.; Buitenhuis, H.; Grupe, G.; Schmidt, K.; Pöllath, N. The Long and Winding Road: Ungulate Exploitation and Domestication in Early Neolithic Anatolia (10000-7000 CAL BC). In Origins and Spread of Domestic Animals in Southwest Asia and Europe; Colledge, S., Conolly, J., Dobney, K., Manning, K., Shennan, S., Eds.; University College London: London, UK, 2013; pp. 83-114.

44. Balos, M.M.; Akan, H. Flora of the Region between Zeytinbahçe and Akarçay (Birecik, Şanlıurfa, Turkey). Turk. J. Bot. 2008, 32, 201-226.

45. Rosen, A.M. The Geoarchaeology of Holocene Environments and Land Use at Kazane Höyük, S.E. Turkey. Geoarchaeology 1997, 12, 395-416. [CrossRef]

46. Ahnert, F. Über die Beziehung zwischen quantitativen, semiquantitativen und qualitativen Methoden in der Geomorphologie. Zeitschrift für Geomorphologie 1981, 39, 1-28.

47. Neteler, M. Open Source GIS: A Grass Gis Approach, 3rd ed.; Springer: New York, NY, USA, 2007. 
48. Hofierka, J.; Mitášová, H.; Neteler, M. Chapter 17 Geomorphometry in GRASS GIS. In Geomorphometry —Concepts, Software, Applications; Developments in Soil Science; Hengl, T., Reuter, H.I., Eds.; Elsevier: Amsterdam, The Netherlands, 2009; Volume 33, pp. 387-410.

49. Beven, K.J.; Kirkby, M.J. A Physically Based, Variable Contributing Area Model of Basin Hydrology. Hydrol. Sci. Bull. 1979, 24, 43-69. [CrossRef]

50. Jasiewicz, J.; Stepinski, T.F. Geomorphons-A Pattern Recognition Approach to Classification and Mapping of Landforms. Geomorphology 2013, 182, 147-156. [CrossRef]

51. Mitasova, H.; Mitas, L. Multiscale Soil Erosion Simulations For Land Use Management. In Landscape Erosion and Evolution Modeling; Harmon, R.S., Doe, W.W., Eds.; Springer: Boston, MA, USA, 2001; pp. 321-347. [CrossRef]

52. Mitasova, H.; Barton, C.M.; Ullah, I.; Hofierka, J.; Harmon, R.S. GIS-Based Soil Erosion Modeling. In Treatise on Geomorphology; Bishop, M.P., Ed.; Elsevier Inc.: Amsterdam, The Netherlands, 2013; Volume 3, pp. $228-258$.

53. R Core Team. R: A Language and Environment for Statistical Computing; R Foundation for Statistical Computing: Vienna, Austria, 2018.

54. Gabriels, D. Assessing the Modified Fournier Index and the Precipitation Concentration Index for Some European Countries. In Soil Erosion in Europe; Boardman, J., Poesen, J., Eds.; John Wiley \& Sons, Ltd.: Chichester, UK, 2006; pp. 675-684. [CrossRef]

55. Leser, H.; Stäblein, G. Geomorphologische Kartierung: Richtlinien zur Herstellung Geomorphologischer Karten 1: 25 000; Institut für physische Geographie, Freie Universität Berlin: Berlin, Germany, 1975.

56. Leser, H.; Stäblein, G. Legend of the Geomorphological Map 1: 25.000 (GMK 25): Fifth Version in the GMK Priority Program of the Deutsche Forschungsgemeinschaft. Berl. Geogr. Abh. 1985, 39, 61-89.

57. Rosen, A.M. Early to Mid-Holocene Environmental Changes and Their Impact on Human Communities in Southeastern Anatolia. In Water, Environment and Society in Times of Climate Change; Issar, A.S., Brown, N., Eds.; Kluwer Academic Publishers: Dordrecht, The Netherlands, 1998; pp. 215-240.

(C) 2019 by the authors. Licensee MDPI, Basel, Switzerland. This article is an open access article distributed under the terms and conditions of the Creative Commons Attribution (CC BY) license (http:/ / creativecommons.org/licenses/by/4.0/). 